\title{
O detido-desaparecido: catástrofe civilizacional, desmoronamento da identidade e linguagem
}

The Detained-Disappeared: Civilisational Catastrophe, the Collapse of Identity and Language

Le détenu-disparu : catastrophe civilisationnelle, effondrement de l'identité et langage

\section{Gabriel Gatti}

Tradutor: Margarida Gomes

\section{(2) OpenEdition}

\section{Journals}

Edição electrónica

URL: http://journals.openedition.org/rccs/77

DOI: $10.4000 /$ rccs. 77

ISSN: 2182-7435

Editora

Centro de Estudos Sociais da Universidade de Coimbra

Edição impressa

Data de publição: 1 Março 2010

Paginação: $57-78$

ISSN: 0254-1106

\section{Refêrencia eletrónica}

Gabriel Gatti, « O detido-desaparecido: catástrofe civilizacional, desmoronamento da identidade e linguagem », Revista Crítica de Ciências Sociais [Online], 88 | 2010, colocado online no dia 22 maio 2012, criado a 01 maio 2019. URL : http://journals.openedition.org/rccs/77 ; DOI : 10.4000/rccs.77 


\section{GABRIEL GATTI}

\section{O detido-desaparecido: Catástrofe civilizacional, desmoronamento da identidade e linguagem}

Este artigo propõe o conceito de catástrofe como ponto de partida para a construção de estratégias de representação adequadas aos fenómenos de violência social extrema, centrando-se no caso do desaparecimento forçado de pessoas na Argentina e no Uruguai. A análise parte de um paradoxo: o processo representa o culminar das políticas de construção e gestão da população na América pós-colonial e, ao mesmo tempo, aplica-se aos produtos mais acabados dessa política, os indivíduos-cidadãos. Devido a esta condição paradoxal, o desaparecimento forçado de pessoas implica problemas insolúveis para as leituras da identidade e da linguagem próprias do "processo civilizador", o indivíduo-cidadão e a representação directa. Deste modo, este desaparecimento situa a identidade e a linguagem no terreno da catástrofe, requerendo o repensar das nossas estratégias de representação.

Palavras-chave: Argentina; catástrofe; civilização; desaparecidos; identidade; representação; terrorismo de Estado; Uruguai; violência social.

Este texto trabalha sobre problemas de difícil solução: saber o que acontece à vida social quando ela se afasta dos parâmetros que a definiam quando os pactos modernos estavam em vigor, especialmente o pacto que vinculou as palavras às coisas e as representações aos factos. Hoje, são muitas as situações em que este pacto se quebra, algumas banais, outras extremas. Neste artigo vou centrar-me numa das últimas, o desaparecimento forçado de pessoas. Trata-se de uma situação limite, que nos obriga a repensar, muito seriamente, as relações entre memória, vida social, identidade e representação.

Para abordar esta situação limite, proponho-me retomar um velho conceito, o conceito de catástrofe. Depois de o apresentar, analiso como o desaparecimento forçado é uma catástrofe porque afecta dois bens ponderosos, a identidade e a linguagem. Seguidamente, exponho alguns esforços para 
contar e esconjurar essa catástrofe, ${ }^{1}$ ambos vãos, pois demonstram que, ante a violência extrema, é acima de tudo necessário não abandonar a representação, mas sim rever as nossas estratégias de representar. Encerro este texto com uma breve proposta quanto à forma de o fazer.

\section{A catástrofe. (Breves) apontamentos teóricos}

Existem factos que se encontram associados de forma estável a sentidos e também factos completamente dissociados do sentido. Esta dissociação pode produzir-se de maneira pontual ou de maneira duradoura. Neste último caso, deparamo-nos com problemas de representação e habitabilidade das situações marcadas por esta dissociação; se essa dissociação entre factos e sentidos se estabiliza, encontramo-nos perante uma catástrofe social. Explicarei o conceito como parte de uma sequência: se o grau zero é a normalidade (factos irmanados com os sentidos), seguem-se a ele três graus distintos de dissociação entre factos e sentidos - o trauma, o acontecimento e, no limite do pensável, a catástrofe:

1. No trauma, a desestabilização é profunda, mas provisória, uma vez que existem instituições capazes de regular os desajustes, competentes para que à desestabilização se siga a institucionalização de um novo equilíbrio. Passado algum tempo, tudo regressa ao seu lugar, normalizando-se. A morte de alguém próximo é um trauma; o luto, quando chega ao fim e se resolve, é uma instituição que permite geri-lo.

2. No acontecimento, a desestabilização é profunda e intensa. Tanto que, quando sucede, a ruptura é absoluta, mas de curta duração. Por ser tão intenso, não existe uma categoria susceptível de o captar. Assim, o acontecimento afirma-se como único e sem nome, mas rapidamente se desvanece; por isso, deixa poucos exemplos: erupções de dor, revoltas poderosas, prazeres imensos. Não deixam rasto.

3. A catástrofe é uma instabilidade estável: o desajuste permanente entre palavras e coisas convertido em estrutura enquanto desajuste. "A catástrofe é uma dinâmica que produz desmantelamento sem constituir outra lógica equivalente na sua função articuladora" (Lewkowicz, 2004: 154). A causa da catástrofe não desaparece: é a excepção permanente, é a anormalidade da norma, é um luto perpétuo... Trauma que não se resolve; acontecimento que perdura. É, sim, a ambivalência feita norma. "Desta vez a inundação chegou

\footnotetext{
${ }^{1}$ Analiso outros esforços na obra que recolhe os resultados das investigações em que se baseia este trabalho (Gatti, 2008). Trata-se de vários projectos realizados entre 2005 e 2008 na Argentina e no Uruguai, financiados pelos planos de mobilidade da Universidade do País Basco e do Governo Basco. No presente texto, analisam-se os resultados referentes aos dois países, mas principalmente os que se referem ao caso argentino.
} 
para ficar" (ibid.). O desaparecimento forçado de pessoas é um exemplo de catástrofe social, ainda que existam outros mais banais: a identidade de um "sem papéis", certas situações de precariedade laboral... Partindo de uma catástrofe social, constrói-se um espaço social muito problemático, que se define pela quebra das relações convencionais entre a realidade social e a linguagem quando esta quebra se consolida e, particularmente, quando essa consolidação comporta dificuldades permanentes para representar o que ocorre nos territórios desenhados por essa quebra. ${ }^{2}$

\section{O desaparecimento forçado. Uma catástrofe em contexto}

Vou tentar demonstrar a utilidade analítica do conceito para a compreensão de situações sociais marcadas pela violência extrema, aplicando-o a um caso concreto, o desaparecimento forçado de pessoas e a figura do detido-desaparecido. Procurarei enquadrar ambas as coisas num contexto social e histórico: o processo civilizador tal como se manifesta (de forma exacerbada) na Argentina e no Uruguai. Nesse contexto, o dispositivo de desaparecimento (Calveiro, 2004) e a figura que ele produz, o desaparecido, manifestam-se, a meu ver, como dispositivo que busca e figura que encarna a desestruturação e a ruptura do mais prototípico dos produtos da subjectividade moderna, o indivíduo-cidadão.

\subsection{Jardineiros, construção de sociedades e indivíduos no processo civilizador do Cone Sul latino-americano}

A Argentina e o Uruguai, como quase tudo na América Latina, são o resultado do sonho civilizador. Ali, "as motivações [do colonizador] [...] para fundar novas cidades no território que acabavam de conquistar e para destruir as antigas cidades indígenas que haviam encontrado pelo caminho correspondiam a um novo desígnio, o de inventar uma nova Europa" (Blengino, 2005: 19). Lugares imaginados como surgidos do nada, como o trabalho de modelação de um deserto que se habita com base num projecto. Vazio que se preenche graças a um preciso trabalho de jardinagem

\footnotetext{
${ }^{2}$ Formulo o conceito baseando-me nas ideias de catástrofe linguística e psíquica. A primeira pode entender-se, com George Steiner e Alvin Rosenfeld, a partir dos efeitos que os fenómenos limite produzem na linguagem. É o caso de Auschwitz, que, para Steiner, submete a linguagem a uma crise de tal profundidade que o leva a afirmar que "está fora da linguagem" (1982), constituindo, para Rosenfeld, um verdadeiro "linguicídio", um caso de "morte da linguagem" (apud Grierson, 1999). Podemos abordar a segunda partindo do trabalho de René Kaes, para quem "uma catástrofe psíquica produz-se quando as modalidades habituais empregadas para tratar a negatividade inerente à experiência traumática se mostram insuficientes, especialmente quando não podem ser utilizadas pelo sujeito devido a qualidades particulares da relação entre a realidade traumática interna e o meio ambiente" (1991: 98). Ou seja: dá-se quando uma situação não pode ser entendida partindo dos mecanismos de compreensão da estrutura que essa situação destrói.
} 
(Bauman, 1997a) que permite que nele (1) se dê forma a uma população (Foucault, 2006), (2) se construa a Cidade Letrada (Rama, 1998), (3) se conforme o sujeito que integra essa população habitante da Cidade Letrada, o indivíduo-cidadão.

\section{A formação da população}

Desde o século XVIII, o governo exerce-se sobre a população, e não sobre o território. É a biopolítica, "o modo" - diz Michel Foucault -, "pelo qual [...] a prática governamental tentou racionalizar os fenómenos representados por um conjunto de seres vivos constituídos em população: problemas relativos à saúde, à higiene, à natalidade, à longevidade e às raças" (1990: 119). Este governo de populações possui uma geneologia e tem os seus protagonistas.

A genealogia do governo de populações encontra-se sem grande dificuldade quando combinada com a ideia de fazer sociedade. Não me alongarei nesta questão. Basta dizer que a sociedade é uma forma de vida social de invenção recente (Donzelot, 1984; Kaufmann e Guilhaumou, 2003) e que comparece no imaginário dos seus muitos preceptores - do republicanismo ao anarquismo, do liberalismo ao socialismo - como um território para a acção correctiva (lugar de políticas e direitos) e para a acção observadora (lugar de sociologias e antropologias). A pena destes preceptores era de tal forma poderosa, que, na sua obra social, eles foram capazes de fazer o que sonharam, a sociedade, uma "noção estratégica" (Donzelot, 1984: 77), que serviu para moldar, modelar e modular, para criar coisas e pessoas.

Coisas e pessoas conformes à lógica do Estado-nação e do indivíduo-cidadão, os protagonistas deste enredo. Tampouco me alargarei sobre isto (Gatti, 2007). Basta apenas recordar que as metáforas que modelam as nossas subjectividades são um legado directo, no plano colectivo, do Estado-nação e, no plano pessoal, do indivíduo-cidadão. Ambos, o maior e o menor, são irmãos, e como tal, são parecidos ainda que dêem uma impressão de rivalidade e conflito. Mas quer queiram quer não, sempre partilharam os mesmos pais (a modernidade) e a mesma lógica: ambas são figuras ordenadas, coerentes, estáveis - como o Estado -, indivisíveis - como o indivíduo. Sempre incontaminadas e no lugar próprio; nunca sujas nem desordenadas. Ambos são o modelo da vida moderna, ao ponto de se terem tornado nos nossos produtores de solidez (Lewkowicz et al., 2003: 171). Constituem a "nossa canção", a melodia que nos seduz, a única maneira que temos de ver a vida social. Não me refiro apenas a referências empíricas, nem a realidades administrativas. Refiro-me às nossas "pan-instituições doadoras de 
sentido", aos nossos "princípios gerais de consistência" (ibid.: 31 e 65), aquilo que para os modernos equivale, e não é pouco, à geometria básica (Moya, 1984).

\section{A construção da Cidade Letrada}

Mas nem tudo é igual em todo o lado: a governamentalidade moderna, aquela que desde o século XVIII encontra na população o seu objecto e o seu produto, e que tem no Estado-nação e no indivíduo-cidadão as suas criaturas dilectas, estende-se por todos os lados, é certo, mas de maneiras diferentes. Tem, pois, esse trabalho de colonização da realidade a sua historicidade e a sua territorialidade: ainda que assim pareça, a história da invenção da sociedade na Europa e a que dá conta desse processo na América Latina não coincidem em absoluto. Na primeira, combateu-se contra o Estado feudal e a política dos guardas florestais (Bauman, 1997a), expoente estilizado da cultura silvestre pré-moderna, sujeito possuidor de um poder que administrava os seus domínios, explica Bauman, com parcimónia e desleixo. Foi frente a essa política que na velha Europa se estabeleceu o "governo dos conhecedores e do conhecimento como força dirigente” (ibid.: 99). Mas não foi assim na América: o Estado não se ocupou com substituir os velhos guardas florestais; imaginou que a sua tarefa era instalar jardineiros para, primeiro, fazerem crescer e, depois, manterem e cuidarem das civilizações.

$\mathrm{Na}$ América Latina, diferentemente da norma europeia, segundo a qual a cidade surge após um longo processo de desenvolvimento ou, em alguns casos, impondo-se à resistência da estrutura feudal, o ponto de partida é o ideal. Assim, a civilização não é um resultado, mas sim um começo.

O trabalho de jardinagem é tão duro no essencial como qualquer outro trabalho de engenharia sociológica; poderoso como este e, seguramente, bem-intencionado e até mesmo belo. E para além de tudo isto, sem mácula: o jardineiro, é sabido, encarrega-se do planeamento do jardim, mas também de limpar as ervas daninhas e de manter imaculado, com uma paciência e persistência admiráveis, o que se encontra dentro dos seus muros:

A cultura moderna é uma cultura de jardim. Define-se como o plano para uma vida ideal e uma administração perfeita das condições humanas. Constrói a sua própria identidade a partir da desconfiança relativamente à natureza. Além do plano global, a ordem artificial do jardim precisa de ferramentas e de matérias-primas. Também necessita de defesas contra o perigo implacável incarnado pela desordem. A ordem, concebida em primeiro lugar como plano, determina o que é uma ferramenta, o que é matéria-prima, o que é inútil, o que é inoportuno, o que é nocivo, o que é uma erva daninha ou um animal nocivo. (Bauman, 1997b: 120) 
Ángel Rama trabalhou sobre a ideia de que a cidade latino-americana nasceu da execução de um plano ilustrado e letrado. Nessa cidade a coisa realiza a palavra, numa época em que a palavra e a coisa começam a entender-se, ou pelo menos a entender-se de acordo com os pactos modernos. A América Latina, continente vazio no imaginário do colonizador, é o lugar propício para iniciar com o pé direito a vida em comum deste casal recém-constituído:

[A] cidade latino-americana veio a ser basicamente um parto da inteligência, pois ficou inscrita num ciclo da cultura universal em que a cidade passou a ser o sonho de uma ordem e encontrou nas terras do Novo Continente o único sítio propício para incarnar. (Rama, 1998: 17)

Terra virgem, tabula rasa, construção ex nibilo, um mundo perfeito, dominado pela representação. Nova Espanha, Nova Helvécia, Nova Leão, Nova Paris... O mesmo, mas sem erros.

É a ordem moderna da representação, isto é, um protótipo que se transpõe para a realidade. Um "princípio de planning", nas palavras de Rama, regeu essa tradução do modelo para o terreno. Ainda hoje, os resultados desse trabalho da representação, pois é a representação que luta contra o vazio a colonizar, são, porque eficazes, marcantes: nasceram cidades, conceberam-se Estados, idealizaram-se imaginários, plenos de utopia, marcados pelo plano a partir do qual foram traçados e pelas cláusulas com que ele vinha enfeitado, entre outras, uma certa obrigação de manter o terreno livre de pragas. Isto é relevante para o meu tema, a catástrofe do desaparecimento forçado de pessoas: condiciona um futuro que continuará a pensar em civilizar, manter e limpar. No fim de contas, esse futuro, o nosso presente, não está tão distante como isso desta origem.

Modernidade no estado paroxístico, sociedade submetida aos olhares do engenheiro/jardineiro, vista como

um objecto a administrar, como uma colecção de problemas distintos a resolver, como uma natureza que há que 'controlar', 'dominar', 'melhorar' ou 'remodelar', como objecto legítimo da 'engenharia social' e, em geral, como um jardim que há que planear e conservar à força na forma em que foi planeado. (Bauman, 1997b: 23)

Quem sustentou esse sonho? Rama fala de auditores, notários, geógrafos, advogados, escrivães, burocratas... Mas a lista é extensível, e chega aos cientistas e aos sacerdotes (Blengino, 2005). E, no extremo, até aos militares de várias cores. 


\section{A fabricação do indivíduo civilizado}

O sujeito que vive nesse belo jardim moderno é o indivíduo. A sua gestão depende, em parte, da sua boa relação com a maquinaria de registo e de socialização dos estados nacionais do século XVIII em diante (censos, escolas, documentos de identidade, registos de pessoas...). E depende também da resposta que seja capaz de dar ao questionário do processo civilizador, às suas exigências de boas maneiras e de autoconsciência (Elias, 1988). Este sujeito tem história, por muito que hoje se tenha tornado a-histórico e o pensemos como um "universal sociológico que acompanha a condição humana" (Béjar, 1988: 15). Não o é; pelo contrário, é algo de invenção recente:

Na praxis social da antiguidade clássica a identidade grupal do ser humano particular, a sua identidade como nós, vós e eles, ainda desempenhava, comparada com a identidade como o eu, um papel demasiado importante para que pudesse surgir a necessidade de um termo universal que representasse o ser humano particular como uma criatura quase desprovida de um grupo social. (Elias, 1990: 182)

Elias aponta pistas para abordar a sociogénese deste singular sujeito que foi e é o indivíduo-cidadão. Em O processo civilizador analisa como o trabalho da civilização acontece conjuntamente com outro de alcance só aparentemente mais modesto, o nascimento do indivíduo moderno. Pode traçar-se a sua génese seguindo ao longo de um caminho em que, à medida que crescem as coacções externas, aumenta o grau de autoconsciência. José María González García resume bem este processo:

Esta transformação pressupõe um processo de auto-constituição do indivíduo, de transformação do seu sistema emotivo, de contenção das emoções, uma mudança nos preceitos das 'boas maneiras' à mesa ou em qualquer reunião da 'boa sociedade', o desenvolvimento de uma grande capacidade de observação psicológica de si mesmo e dos outros [...]. Constitui-se um tipo de homem calculista, sempre na defensiva, repressor das suas reacções emotivas espontâneas, grande observador e conhecedor do seu próprio eu e um bom perito na observação psicológica do ser humano. (2001: 47-48)

A civilização traduz-se em psicologização no plano das economias afectivas ou, o que significa o mesmo, em racionalização. A sociedade encontra por fim o seu parceiro ideal no plano das subjectividades pessoais. Weber e Freud unem-se pela mão do processo civilizador. A sociedade encontra o seu equilíbrio - as disposições de necessidade coincidem com as directivas da acção: 
As coacções sociais externas vão-se convertendo de diversos modos em coacções internas, assim como a satisfação das necessidades humanas passa pouco a pouco a realizar-se nos bastidores da vida social e é carregada com sentimentos de vergonha e como a regulação do conjunto da vida impulsiva e afectiva se vai tornando cada vez mais universal, igual e estável através de um autodomínio contínuo. (Elias, 1988: 449)

Agora, a sociedade revela-se como uma agregação de indivíduos autocontrolados: pudicos, decorosos, submetidos às maneiras à mesa, dotados de uma psique - a psique civilizada - com um grau crescente de diferenciação interna, indivíduos que não defecam nem salivam em público, que comem bem e comem do mesmo modo. São os habitantes ideais da Cidade Letrada. Não são máquinas; muitas vezes, inclusivamente, participam da vida pública e acreditam na cidadania e até na possibilidade de a mudar e melhorar. A Argentina e o Uruguai estão cheios de gente assim.

Essa é a pureza do "modo de operar americano" do processo civilizador. São lugares que nascem da letra civilizadora, que, sumida numa espécie de efervescência nominalista, rebaptiza tudo o que encontra:

Mudam-se e inventam-se novos nomes para os minerais, as plantas e as pessoas. Classificam-se cientificamente arbustos e ervas. Também os religiosos mudam o nome das pessoas e recorrem ao número para verificar o êxito da obra de evangelização. (Blengino, 2005: 56)

A Cidade Letrada, como acertadamente a denominou Ángel Rama: a vida como resultado da escritura (e do censo, e do aparelho judicial, e do documento nacional de identidade). Foucault e Elias desenharam a Argentina e o Uruguai. Outros povoaram-nos com indivíduos. Esses indivíduos foram devastados pelo dispositivo de desaparecimento.

\subsection{O dispositivo de desaparecimento. Elias no campo de concentração}

A paisagem de fundo do desaparecimento forçado é uma sociedade fundada numa retórica em que laboram o discurso da criação ex nibilo e o da eliminação do que sobra, na qual pesa tanto a construção do que se ajusta ao projecto como o desaparecimento do disfuncional e conflitual.

Não se trata apenas de uma interpretação do analista; também os autores do golpe de Estado de 1976 na Argentina se denominaram, pomposamente, de condutores do "Processo de Reorganização Nacional" e mobilizaram velhos imaginários sobre os Estados-nação desta região como 
Estados constituídos na dialéctica entre a ordem e a desordem, entre a civilização e a barbárie (Blengino, 2005). Eles eram a continuação da obra iniciada na Campanha do Deserto, quando a população indígena do que hoje é a Argentina foi aniquilada.

Mas como foi possível que isto ocorresse em países pensados por todos - sobretudo por uma parte importante dos neles nascidos, incluindo este que escreve - como letrados, formados a golpes de citações literárias, com duas capitais que são mais europeias do que muitas das europeias, porque formam uma síntese destas? É certo que é tentador argumentar que a tortura ou, numa escala de brutalidade superior, o desaparecimento forçado, contrariaram a regra do progresso dos processos civilizadores, que foram retrocessos que expressaram que restava algo por domesticar, que "são necessários ainda mais esforços civilizadores” (Bauman, 1997b: 17). Mas, ao invés da hipótese de uma derrocada civilizacional ou de uma súbita barbarização, talvez seja mais ajustada a hipótese que sustenta que aquilo a que assistimos é ao paroxismo da racionalidade. Isto é, que as ditaduras dos anos setenta, mais do que violentarem as sociedades argentina ou uruguaia, mais que conduzi-las a excepções na sua história, revelaram que nelas havia não poucas instâncias "preparada[s] para servir com facilidade a empresa de extermínio" (Vezzetti, 2002: 152).

Essa é a hipótese: o desaparecimento forçado de pessoas não é barbárie, mas sim modernidade exacerbada. Não é senão esta a proposta a partir da qual Zygmunt Bauman (1997b) analisa o Holocausto, quando defende que este fenómeno não é alheio na sua lógica à nossa modernidade iluminada, tanto nas suas manifestações mais espectaculares (a racionalidade científica ou a construção da ideia de cidadania) como nas mais banais (o trabalho minucioso de limpeza do jardineiro, a relação dedicada de um médico com o seu doente...). O Holocausto foi um "laboratório sociológico" (ibid.: 15) de enorme calibre, que deu muitos sinais, não do perigo de retorno à barbárie pré-social, mas das "possibilidades ocultas da sociedade moderna" (ibid.). Essa devastação é a apoteose do sonho civilizador:

O holocausto [...] encaixava por completo em tudo o que sabemos da nossa civilização, do espírito que a guia, das suas ordens de prioridade, da sua visão imanente do mundo e das formas adequadas de atingir a felicidade humana no seio de uma sociedade perfeita. (ibid.: 11)

A Campanha do Deserto na Argentina; o desaparecimento forçado; Auschwitz... Todos estes fenómenos são "inquilino [s] legítimo[s] da casa da modernidade, inquilino[s] que não se teria[m] sentido bem em nenhum 
outro edifício" (ibid.: 23); todos têm, não pode haver dúvida, fortes parecenças de família com o moderno.

Esta hipótese ajuda a entender o sucedido nos anos setenta na Argentina e no Uruguai como uma radicalização do projecto moderno. Tem por isso razão Hugo Vezzetti quando afirma que "a ditadura [argentina] foi tanto uma irrupção como um desenlace” (2002: 16).

\subsection{O paradoxo do detido-desaparecido, uma invenção local}

Neste contexto do processo civilizador, das políticas de população, da (re)construção da Cidade Letrada estritamente planificada, a maquinaria trabalha com automatismos, desde o século XVI até aos anos setenta, até hoje: estamos perante o Estado a desenvolver uma política de população, a fazer de jardineiro. O seus tratadores velam para que o Éden continue a sê-lo e que, se algo saiu dos eixos, seja enquadrado e reorganizado. Cunhar com a civilização o deserto, cuidar que o que se planta cresça bem, continua a ser o objectivo. Mas nem tudo é uma repetição da história. Há duas grandes novidades; sobre uma, o centro clandestino de detenção, a epítome do espaço biopolítico, um lugar de controlo extremo sobre a vida (Calveiro, 2004; Gatti, 2008), não me debruçarei. Sobre a outra, sim; o desaparecido, uma catástrofe abismal.

Pois assim é, aqui, o poder exerceu-se como sempre tem feito: sobre as entidades que rompem a ordem. E esta não foi uma excepção. Ou sim, pois teve uma enorme singularidade: as entidades objecto de desaparecimento forçado foram os produtos mais refinados do próprio trabalho civilizador, os indivíduos com carta plena de cidadania, racionais e ilustrados, asseados (ou sujos por escolha própria). Os frutos perfeitos da modernidade são os que vão ser despedaçados pela maquinaria que foi a sua condição de possibilidade.

Essa força enorme, a força civilizadora, fez esta paisagem. E se é necessário, desfá-la. Tomou como objecto da sua acção - e atrever-me-ia a afirmar que isto é historicamente inaudito, de tal modo que resulta teoricamente fascinante e moralmente terrível - o seu próprio produto, o indivíduo moderno e racional, de identidade referendada com credenciais cívicas e administrativas. $\mathrm{O}$ indivíduo limpo e autoconsciente do Estado-nação, da cidadania liberal. O sujeito que encontra sentido no divã psicanalítico. E desfê-lo. É, como digo, uma verdadeira invenção, tanto que merece um nome, o do paradoxo que o constitui, "o paradoxo do detido-desaparecido", que poderia enunciar-se assim: (1) o desaparecimento forçado faz parte das ferramentas de construção e gestão da população próprias da ordem civilizadora/moderna; (2) o desaparecimento forçado aplica-se aos produtos mais acabados da ordem civilizadora/moderna. 
Assim foi, a rotina civilizadora aplicou-se ao mais acabado da civilização. É uma máquina civilizadora invertida; des-civilização, que não é o mesmo que barbárie.

A conjuntura da época, os militares treinados na Escola das Américas, a doutrina da segurança nacional e a produção generalizada do inimigo interno, as experiências nazi, espanhola ou do Vietname. Atender a esses factores explicaria muito, sem dúvida, deste episódio. A verdade deve estar por aí. Mas nenhum deles pode dar conta do sublime do horror que provocou - e provoca - o desaparecimento forçado de pessoas: provavelmente sem querer, inventou-se um instrumento devastador do sentido. Uma catástrofe: "Umas bestas pintaram La Gioconda e, na realidade, estavam a matar uma mosca com um pincel [...]. Fizeram coisas incríveis, separaram uma identidade de um corpo, foi isso que fizeram". ${ }^{3}$

\section{O desaparecimento forçado de pessoas como catástrofe na identidade e na linguagem ${ }^{4}$}

O desaparecido é uma emergência, uma singularidade, uma consequência não intencional, um não-previsto. É um indivíduo despedaçado; um corpo separado do nome; uma consciência alheada do seu suporte físico; um nome separado da sua história; uma identidade desprovida das suas cartas de cidadania. É um "corpo a que acontecem coisas", diz a filha de um deles. Pura vulnerabilidade.

Perante ele, "a palavra pressente a ameaça do seu esgotamento [...]. A ameaça do seu próprio esgotamento fere-a [...] no seu poder essencial e original, o de nomear" (Gómez Mango, 2004: 15). Por isso, apenas com a conjugação de termos de semântica difusa se pode definir o desaparecimento e as suas figuras: chupado, separado, dissociado; borrado [apagado], sujeito impossível de registrar no repertório da existência estruturada; chupaderos, lugares de excepção, onde um sujeito era absorvido, abduzido quase, pelo mecanismo de desaparecimento. $\mathrm{O}$ desaparecido, diz ainda Gómez Mango, é um desamparado, um "morto-vivo" um "morto roubado à morte", um "sempre presente na própria ausência" (2004: 17). ${ }^{5}$ E essa

\footnotetext{
${ }^{3}$ Entrevista realizada a um membro da Equipa Argentina de Antropologia Forense.

${ }^{4}$ As citações das próximas epígrafes correspondem a entrevistas levadas a cabo, no âmbito das investigações mencionadas (cf. nota 1, supra), com membros da Equipa Argentina de Antropologia Forense ou da Associação de ex-detidos-desaparecidos. Nalguns casos, foram colhidas no arquivo da Fundação Memoria Abierta de Buenos Aires.

${ }^{5}$ Gómez Mango, baseando-se em Arendt, propõe incluir o desaparecido no rol dos desamparados da existência: precários, clandestinos, sem papéis, refugiados, párias...: "A noção de desamparo [...] parece-me a que melhor se presta para descrever e compreender o sofrimento psíquico destes párias da modernidade" (2004: 101), uma "experiência íntima de sentir-se radicalmente expulso do humano" (ibid.: 8).
} 
ausência é um estado (é-se desaparecido), não uma situação (não se está desaparecido): "A categoria de desaparecimento implica uma presença-ausência que se mantêm ao longo do tempo" (Kordon e Edelman, 2005).

Estamos perante um novo estado do ser, situado num lugar inaudito. Pensávamos que, na arquitectura da existência, não havia lugar possível entre a vida e a morte e se havia (purgatório, limbo, fantasmas, espectros...), durava pouco. Mas o desaparecimento inventa um espaço de instabilidade perpétua, uma espécie de liminaridade permanente. De resto, irresolúvel: nem sequer se fecha com a certeza da morte do sujeito desaparecido.

É claro que a catástrofe é enorme; a dissociação permanente: uma entidade que teve o estatuto de indivíduo-cidadão é expulsa para o território de fora, para onde eram antes enviados os vagabundos ou a escória, convertido como eles em NN. ${ }^{6}$ Deixa de ser cidadão e passa a ser desaparecido. Assim, de facto, desaparecer não se conjuga com o verbo estar; é algo que afecta o verbo ser: "Quando me disseram 'tu estás desaparecido'; não me disseram na realidade 'estás desaparecido', mas és um desaparecido". Cria-se nada menos do que um novo estado do ser ("Nem vivo nem morto, é um desaparecido", "Uma não pessoa, algo que não se sabe se existe”). Um estado inédito, "um abismo novo".

É certo que o desaparecimento forçado de pessoas ocorreu noutros capítulos da história: por exemplo o decreto Nacht und Nebel (Noite e Nevoeiro), de 1941 (Amnistia Internacional, 1983), que parece ser o antecedente histórico directo da figura, que se manifestara também na Guerra Civil espanhola ou acontece hoje em campos como o de Guantánamo. Ou inclusivamente na própria Argentina, na zona indígena de Tucumán, onde foi especialmente virulenta a política de desaparecimento forçado e os efeitos foram tão terríveis como nas zonas urbanas. Em qualquer destes casos, a estratégia, aplicada sistematicamente, é, além de sinistra, eficaz.

Mas não foi a mesma coisa.

Não se trata de uma questão de parcialidade, e menos ainda de comparar horrores. Reitero a minha hipótese para argumentar esta questão: ali, nas civilizadas capitais do Cone Sul, o desaparecimento forçado afecta radicalmente, e destroça, as formas de representação da identidade e do sujeito, enquanto, nos lugares que mencionei, é plausível recorrer a figuras que,

\footnotetext{
${ }^{6} \mathrm{NN}$ designa as tumbas de desconhecidos ou as valas comuns. Significa nomen nescio ("desconheço o nome") ainda que, por erro de tradução e não de semântica, se traduza por "Nenhum Nome" ou "No Name". Nos anos oitenta na Argentina apareceram numerosos esqueletos em tumbas NN de cemitérios públicos que foram identificados como de pessoas desaparecidas.
} 
nas tradições locais, explicam a existência de corpos sem identidade ou de nomes sem corpos. ${ }^{7}$

O que aqui se desmorona é o pilar da nossa forma de entender a identidade, o indivíduo, que é devastado: perde o nome, fica sem território, é separado da sua história. A catástrofe é assim: as coisas não têm palavras para lhes dar consistência; as que existem não servem: estamos perante uma figura que se representa como sem lugar ("O desaparecido não deixa rasto, cria um vazio"), que não encaixa em nenhuma entidade reconhecivel, simultaneamente ausente e presente ("[Com eles] a ausência converte-se em presença"), sem lógica ("O desaparecimento é um atentado à lógica. Provoca um sentido de absurdo"), sem corpo ("É um corpo sem identidade e uma identidade sem corpo"). Território impreciso, entre a vida e a morte; território realmente pantanoso: palavras e coisas fundem-se; a sua união destrói-se. Uma catástrofe.

Ou duas: a que assolou a arquitectura moderna da identidade; a que arruinou a possibilidade de representar. Abordo a primeira através do esforço para reordenar os fragmentos restantes das identidades desaparecidas, para reunificar corpos e identidades. A segunda, através do trabalho de dar testemunho do que ocorreu no campo. São muitos os organismos que contribuíram para dar forma a uma e outra. Escolho, para ilustrar esse trabalho, dois dos mais característicos: a Equipa Argentina de Antropologia Forense, que trabalha sobre o estatuto da identidade despedaçada; a Associação de Ex detidos-desaparecidos, que elabora estratégias para dar uma linguagem ao horror.

Ambos os esforços pretendem ordenar a catástrofe, introduzir ordem (imaginário) no caos (do imaginário) que o desaparecimento forçado de pessoas provoca. Obtêm muita coisa: pensar o desaparecimento, a capacidade de denúncia... Mas concluem quase sempre no desespero da sua própria impossibilidade ou, o que vem a ser o mesmo, com a constatação da incomensurabilidade da catástrofe relativamente aos recursos de que nos socorremos para pensá-la.

\footnotetext{
${ }_{7}$ Como sucede em Tucumán, no Norte argentino, onde se fala dos inausentes, tal e como me comunicou a investigadora argentina Mecky Vega. Ali pensava-se o desaparecimento invocando figuras tradicionais ("foi levado pelo Familiar", "foi levado pelo Cão"), algumas das quais procedentes dos tempos da Conquista. É plausível trabalhar com a hipótese de que nessas tradições existem figuras a que acudir para gerir o desaparecimento forçado e suas consequências, figuras que amortizam o dor que provoca o desaparecimento forçado, o qual, quando se desenrola em zonas que não dispõem desses amortizadores, não tem com que conter-se. Não se trata de uma vantagem: indica que o horror não é excepcional, que integra uma série continuada de opróbios, tal como outrora, agora vinham "os homens armados".
} 


\subsection{A catástrofe da identidade e seu (impossível) esconjuro}

Do desaparecido pouco resta: informações sobre o antes da sua condição como tal, testemunhos (incompletos, inseguros) da sua passagem pelo centro clandestino de detenção. Materialmente, resta, muito poucas vezes, um corpo sem identidade; no resto das vezes, uma identidade sem corpo, um nome de alguém que se sabe que é um detido-desaparecido sem rasto do seu corpo. Pode ser que subsistam - vantagem de ter sido a máquina civilizadora, o Estado, que o deglutiu -, restos burocráticos, maços de papel, rastos com selo reveladores da saída de alguém, momentânea ou final, das catacumbas da maquinaria de desaparecimento e do seu ingresso nas partes mais visíveis e conhecidas do aparelho de Estado, prolífico nestes lugares em instituições e personagens: funcionários das morgues que enterram e dão fé; médicos e enfermeiras das urgências que atendem uma jovem baleada e lavram acta no registo do hospital público; peritos e polícias de serviço nocturno que, por rotina, fotografam um corpo aparecido na rua e adicionam o relatório a um processo; arquivadores do Estado que guardam alguma cópia dactilografada desse corpo sem nome; magistrados de turno que verificam e atestam que esse corpo não é "de ninguém" e que o destino dessa não-identidade é a vala comum do cemitério público. Mas o mais comum é que nem esses restos fiquem e que apenas seja possível aceder - estranha e perversa redundância - às informações que indicam que houve outros que anteriormente pediram informações sobre aqueles que estão hoje desaparecidos: registos de habeas corpus solicitados pelas mães, cópias de denúncias de desaparecimento apresentadas pelos cônjuges impossibilitados de aceder como sujeitos jurídicos perante o Estado para heranças, compras, vendas... pois o estatuto impossível dos seus cônjuges bloqueia-o... Nada mais.

Aqui, as coisas que fazem a identidade moderna aparecem em fragmentos. Nesse trabalho de fragmentação, de despedaçamento de um sujeito, reside a chave teórica, segundo muitos agentes, do desaparecimento forçado de pessoas:

1. Despedaçamento primeiro daquilo que se lê como unidade ontológica do ser humano, a que reúne um corpo e só um com um nome e apenas um. A EAAF (Equipa Argentina de Antropologia Forense) refere: "O que a repressão clandestina fazia era transformar uma coisa em duas; identidade e corpo são a mesma coisa, têm que ser a mesma coisa; num dado momento, é como se se passasse por um lugar, por uma paragem, onde duas coisas que formam uma só se dissociam". Terrível funcionamento o desta maquinaria, que desfez a unidade, naturalizada no sujeito moderno, entre corpo e consciência, a condição do nosso equilíbrio ontológico. Manobrou recortando, 
dividindo, dissociando esse indivíduo íntegro. Não fez menos do que romper com a coexistência numa entidade sempre idêntica a si mesma (o semper idem da identidade) de um corpo, mutável mas íntegro, e de uma consciência, mutável mas, essencialmente, uma. O que deriva desta desagregação é uma figura nova: o desaparecido, sujeito, mas sujeito despedaçado, identidade, mas pseudo-identidade. Um novo estado do ser, um corpo separado do nome, uma consciência apartada do seu suporte físico.
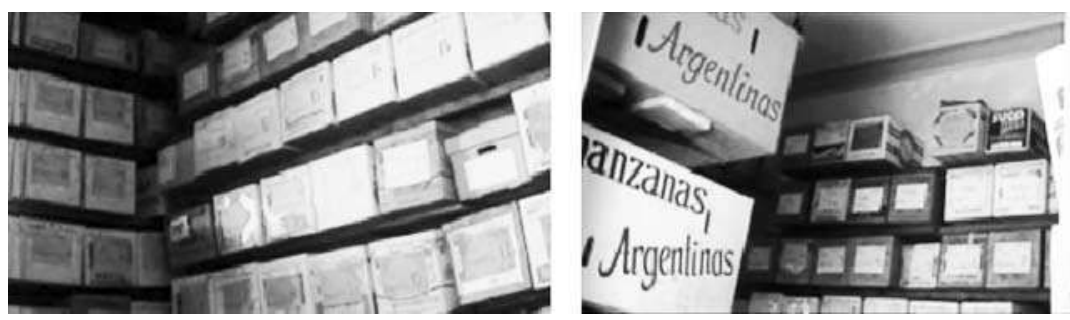

Esqueletos dissociados do seu nome na sede da EAAF, Buenos Aires, Argentina. Fotogramas retirados do filme Nietos. Identidad y memoria (Ávila, 2004). O passo seguinte transcreve a intervenção de um membro da EAAF, nesta mesma película: "O que ainda não pudemos fazer em todos estes casos [olhando para as caixas] foi estabelecer uma relação de sentido que permita reequilibrar novamente a relação básica que todos temos entre a nossa identidade e o nosso corpo. O terrorismo de Estado o que fez, entre outras coisas, nestes casos foi dissociar, fazer com que uma identidade e um corpo se separassem. A identidade fica no ar, e o corpo fica ali. O propósito deste trabalho é que a coisa não fique como a deixaram, e deixaram-na assim [apontando para as caixas], com as identidades apartadas do seu corpo".

2. A maquinaria despedaçou esse nome e esse corpo unidos numa identidade na sua associação com uma continuidade, a do romance familiar, veiculado pela filiação: "O ocorrido, o desmantelamento dos direitos das pessoas através do desaparecimento e do assassínio e o rapto de crianças, hoje jovens e ainda desaparecidos, conduziu a uma ruptura do sistema humano de filiação, é um massacre dos vínculos e uma fractura da memória" (Lo Giudice, s/d).

3. A maquinaria despedaçou, finalmente, a relação desse indivíduo, que é corpo e consciência encadeada numa história familiar, à unidade administrativa que lhe dá sentido como cidadão, o Estado. Foi despojado dos direitos de cidadania e deu-se conta disto em termos semelhantes aos que o jardineiro moderno empregava para se desfazer das ervas daninhas: turba, gente sem amos, classe dangereuse, vagabundos, nómada, ralé, mobile vulgus, banido, racaille, linyera ${ }^{8}$ subversivo... Gente sem nome.

${ }^{8}$ Designação utilizada na Argentina para pessoas vagabundas. 
Estas três leituras do despedaçamento que o desaparecimento forçado de pessoas provoca permitem medir a profundidade da catástrofe que este fenómeno ocasiona na nossa leitura da identidade. E perante esta, a reação é gerir o desastre refazendo o que se desmorona; noutros termos, re-associar o que o desaparecimento quebrou, o pacto entre palavras-nomes e coisas-corpos. É o que faz a Equipa Argentina de Antropologia Forense, trabalhando sobre o que resta desse pacto, reconstruir, devolver o sentido. Trabalha no limite do possível. Refaz o operar da máquina invertendo-o e assim, se ela, como defendo, des-civilizou, esforça-se por recivilizar: procura reequilibrar as relações entre corpo e nome (recuperar a identidade), re-fazer o indivíduo, reinscrevendo-lo na sua história familiar (fazer o luto) e na sua condição de cidadão (inscrevê-lo oficialmente como morto). Muito trabalho: operar com a lógica da máquina burocrática, que dá e tira identidade, mas invertendo-a:

- Desde o nascimento de uma pessoa, atribui-se-lhe um número e uma identidade, ninguém escapa a isso. [Sem isso] não se pertence ao Estado, não se é um indivíduo de pleno direito. O que se passa é que essa forma de registo populacional é utilizada [no desaparecimento] com outra tendência

- [GG] É também, basicamente, a mesma que vocês estão a pôr em prática...

- Claro, mas em sentido inverso.

Com uma finalidade, recompor a identidade que se despedaçou:

- [GG] Identificar é devolver a identidade?

- Claro, eu quebro esta chávena e tenho que a voltar a colar, o que faço com os cacos?

O que era isto? Era uma chávena, então tenho de voltar a ter uma chávena, se tenho todos os pedacinhos... nunca tenho todos os pedacinhos, mas tem que ser o mais parecido possível com uma chávena.

\subsection{A catástrofe da linguagem e o seu (impossível) testemunho}

Vós sois o que nós fomos, nós somos o que vós sereis Inscrição à entrada do cemitério velho de Orereta, Guipúzcoa

Giorgio Agamben (1998) propôs que se pensasse o campo de concentração nazi como um espaço construído sobre a lógica da excepção, o princípio segundo o qual a lei ordena a sua própria desobediência (ibid.: 30). Quando a excepção se realiza, dão-se duas circunstâncias. Primeiro, uma delimitação estrita (a excepção acontece num mundo à parte); depois, 
uma linguagem própria desse mundo à parte, mas inadequada para o mundo que este contradita, aquele a respeito do qual é excepção; essa linguagem possui uma gramática incómoda, é tartamuda: a excepção obriga ao balbuceio. Os dois dados coincidem nos relatos, nos poucos relatos, que saíram dos centros clandestinos de detenção, os chupaderos no jargão da própria maquinaria repressiva, sítios onde se suprimia toda a ligação com o exterior e o detido-desaparecido entrava num lugar cuja quotidianidade decorria "nos confins mais subterrâneos da crueldade e da loucura” (CONADEP, 1987: 59). Lugar de regras que rompem com a Regra: ali, disse-me um ex-desaparecido "acabou-se a lei da gravidade"; ali, contou outro, "não se aplicavam as regras de fora. Passavam-se todos os limites". Um terceiro explica:

O que é o que não é transmissível? Os mortos? Os desaparecidos? As torturas? Tudo isso se entende. Quero dizer, entende-se com a cabeça. O que é que não se entende? Não se entende a anomia, não se entende a falta de regras.

Pilar Calveiro, no testemunho da sua passagem pela Escola de Mecânica da Armada, o chupadero mais conhecido, descreve-o assim: "existe uma sensação muito clara de que se está numa dimensão que é outra, num mundo à parte"; separado do mundo de fora, o campo de concentração, diz ela, é uma "irrealidade real regida por outras lógicas" (Calveiro, 2004). Graciela Daleo, outra sobrevivente da ESMA, testemunha deste modo sobre os "passeios" fora do chupadero onde estava desaparecida: "Dizia a mim própria que estava aqui, mas na realidade não era deste mundo". Mundo on de regras claras; mundo off, invisível, escuro, desaparecido, excepcional.

Desse espaço excepcional, dessa franja de realidade em que a norma fica suspensa e cuja ordem se define por essa suspensão (Agamben, 2002: 222), saem os agentes - os ex detidos-desaparecidos - do testemunho. São os ex-desaparecidos; ocupam um lugar complicado, de difícil administração num mundo que se dá mal com o fora de série e que, enfermo como está de horror vacui, aborrece o sem sentido: estão no espaço inquietante do entre-dois, num limbo paradoxal, num purgatório ambivalente ("Nós continuamos a não estar em parte alguma"; "Por vezes senti ser um fantasma, ninguém nos ouvia, ninguém acreditava em nós”). Lugares tão aberrantes como anormais, sempre impossíveis. O ex-desaparecido ocupa um lugar difícil. Como continuar agarrados a uma identidade, a dos desaparecidos - habitantes do buraco - se, ao sair do buraco, deixaram de o ser? Como reclamar continuar a falar como desaparecidos se, precisamente por poderem falar, deixaram de o ser? 
O primeiro passo para esconjurar esta catástrofe é encontrar um nome comum que designe essa difícil posição colectiva: "Aparecidos", "Desaparecidos reaparecidos", "Fantasmas", "O desaparecido que aparece". O segundo, dar sustentação a esse nome comum construindo um lugar de enunciação socialmente partilhado, uma communitas, neste caso, a Associação de Ex-detidos-desaparecidos, suporte comunitário na Argentina do relato de muitos ex-, o que deu plausibilidade à sua identidade de grupo: "Um lugar próprio", "Um pouco o nosso grémio, o grémio dos sobreviventes". Um lugar partilhado, mas complexo, trampolim para a encenação de um estigma comum, uma chaga viva ("Somos uma ferida aberta, somos os que trazemos no corpo as marcas dos campos", "Somos os que saímos da morte", "Somos os que regressam do vazio"). E, uma vez constituídos o nome comum e o lugar partilhado, o terceiro passo é falar a partir deles.

Essa fala manifesta-se como testemunho. Para muitos é quase um ofício: o de terstis, o que intermedeia, o que veicula a informação, uma espécie de médium (Agamben, 2002: 15).9

Mas de que dá testemunho a testemunha? E como? Agamben, baseando-se em Primo Levi, analisa as relações que se estabelecem entre dois tipos de personagens dos campos: os que sucumbem e os que se salvam. Os segundos, sobreviventes, podem dar conta do campo, mas apenas relativamente; os que o viveram não podem contá-lo: viram a Gorgóne. ${ }^{10}$ Os primeiros testemunham, representam; os segundos, mudos, são representados. Os primeiros estão encerrados no absurdo de um impossível: falam de algo de que se abeiraram, mas que não tocaram. É isso que Agamben se propõe designar como "Paradoxo de Levi": "O muçulmano é a testemunha integral" (2002: 85, 157, 172); "eu testemunho pelo muçulmano" (ibid.: 172). Adaptado ao nosso contexto, seria: (1) o desaparecido é a testemunha integral; (2) o ex-desaparecido fala no lugar do desaparecido.

Assim, quem pode testemunhar não tem a palavra; quem tem a palavra não tem nada a dizer. Desesperante, como assumem alguns deles: "O ónus está sobre os desaparecidos e eles não podem dar testemunho, não podem falar.

\footnotetext{
9 Segundo Agamben (2002: 15ss.) o testemunho é terstis: o que intermedeia ("terceiro num litígio entre dois sujeitos" (ibid.: 156)); superstes: o que vive uma experiência até ao final e sobreviveu a ela e por isso pode referi-la; auctor: o que faz surgir o testemunho, um narrador. Ou seja, o que narra um facto a que sobrevive com a intenção de informar, ainda que esse facto seja algo a que não se sobrevive, que não é reportável, que não se pode contar.

${ }^{10}$ A Górgone é a divindade grega que tinha o poder de matar quem a olhasse. Diz Levi: "Não somos nós, os sobreviventes, as verdadeiras testemunhas [...]. Nós, os que sobrevivemos, somos uma minoria anómala [...]: somos aqueles que pelas suas prevaricações, ou pela sua habilidade ou sorte, não tocaram o fundo. Quem o fez, quem viu a Górgone, não voltou para contar ou voltou mudo; são eles, os 'muçulmanos', os que sucumbiram, as testemunhas integrais [...]. Eles são a regra, nós a excepção." (1989: 72-73; sublinhados meus).
} 
Que nós, os que passamos de alguma maneira pelos lugares por onde passaram os desaparecidos, o estejamos a fazer, parece-me... falso", "são eles as testemunhas". Constatam, prisioneiros do paradoxo, que quem realmente pode testemunhar não tem a palavra e que quem tem a palavra não tem nada a dizer:

O testemunho apresenta-se aqui como um processo em que participam pelo menos dois sujeitos: o primeiro, o sobrevivente, pode falar mas não tem nada interessante para dizer, e o segundo, o que 'viu a Górgone', o que 'tocou o fundo', tem muito para dizer, mas não pode falar. (ibid.: 126).

\section{Conclusão: representar a catástrofe}

De que podem falar os que, ainda que tendo-o rondado, não experimentaram o horror até ao extremo? Como dar conta desta catástrofe da linguagem? Alguns ex-desaparecidos optam por uma reviravolta: falar do vazio que se abre entre o desaparecido (o facto na sua intensidade) e eles, as testemunhas (capazes de dar representação ao facto). É nesse vazio que se situa o testemunho e é essa a tensão que expressa: a tensão, terrível, a que o desaparecimento forçado submete a linguagem. Alguém disse, com acerto, que o testemunho das situações limite é o discurso que dá "expressão linguística ao inominável" (Sucasas, 2002: 333), e não pelo que tem de representação da verdade mas antes por ser o melhor reflexo da impossibilidade de alcançá-la nessas situações, do desespero de não poder contar, de não ter palavras. Ele dá palavras, palavras truncadas, a um lugar de que a palavra foi expulsa. Assim, os sobreviventes "testemunham sobre um testemunho que falta. Dão testemunho da impossibilidade de testemunhar" (Agamben, 2002:34).

Não é de estranhar, então, que um ex-desaparecido se pergunte, impotente, ao começar o seu testemunho "Como estruturar este delírio?" e que outro confesse "Se eu tivesse que contar o que creio que foi a experiência da condição de desaparecido... teria que ficar em silêncio, teria que me calar". Tampouco é de estranhar que eles pensem que o ocorrido é, definitivamente, irrepresentável:

A experiência do vivido pode-se contar, mas creio que há uma pequena parte que [...]. Há algo que passa para o outro lado, tem outro registo.

O balanço da minha experiência tem que ver justamente com a dificuldade de transmitir isto, há algo impossível de transmitir...

As narrativas a que Vezzetti (2000) chama narrativas do chupadero, isto é, os relatos saídos do centro clandestino de detenção, têm uma estrutura singular. Quando o ex-desaparecido regressa do campo, crê renascer: volta 
a estar inscrito, reincorpora-se nas coisas a que chamamos "normais", ainda que seja a burocracia idiota de uma prisão comum ou de uma penitenciária em pleno estado de excepção. A realidade é recuperada e "reaparece a palavra", explica uma sobrevivente. Mas a palavra que reaparece não serve para testemunhar o vivido, pois refere-se a outra coisa. Saiu de um universo enterrado, passou para outro com luz. Cada um com a sua lógica, mas intraduzíveis entre si. $\mathrm{O}$ que funciona aqui, não funciona ali. $\mathrm{O}$ vivido não encontra lugar na linguagem conhecida.

Para o impossível, não há referência. Não: por muito que se traduza no objectivo e objectivante de um testemunho que se queira fiel ao sucedido, ou que se tente conduzir o não que não pode ser inscrito num quadro de racionalização partilhado socialmente no âmbito do qual um facto aberrante possa ficar inscrito (por exemplo, a linguagem da explicação política, ou o quadro, algo mais sinuoso mas também apetrechado de causalidades cómodas, da atribuição ao repressor de uma perversão moral), por muito que se faça isso, dizia, há um desespero que permanecerá sempre latente em quem o disse). Um desespero que é, primeiro, o de o que está a ser contado estar mal contado ("Há algo que não é compreensível nesta experiência"; "Há algo aí de uma experiência, não digo... não quero dar-lhe o nome de inefável, mas sim"); e um desespero que é também o de estar a contar apenas a superfície ("[Ao contá-lo] vais-lhe retirar tudo o que sentiste quando o viveste, como que o vais converter numa coisa, assim, material”). É esse o testemunho do ex-desaparecido: o desespero de não poder representar. Roçaram a catástrofe e isso, dizem alguns, "Não pode explicar-se. Como será possível explicar toda essa enormidade!”. E, no campo, “desaparece também a palavra”.

A repressão clandestina construiu um lugar de exercício de poder que se aplicou, provavelmente, com a banalidade do gesto do burocrata, que reprimiu a golpes de rotina. $O$ centro clandestino de detenção ajudou a fazer crescer esse poder além do que o burocrata controlava, até ao espanto. Era um lugar de excepção, onde a linguagem não funcionava, de que mal se pode falar, sobre o qual apenas é possível balbuciar, tartamudear. O testemunho é a fórmula para o fazer. Ele dá palavras a essa catástrofe que é o desaparecimento forçado: assinala as falhas, os buracos, as fendas da representação. Os seus porta-vozes são os agentes que vivem nessa anfractuosidade que se conforma na ruptura entre as palavras e as coisas e que, para falar dela, elaboram uma linguagem que diz da impossibilidade de dizer.

Se existem situações catastróficas, queremos, presos do borror vacui, dominá-las e saturá-las de sentido. É o que fazem perante o desaparecimento forçado antropólogos forenses e ex-desaparecidos: os primeiros querendo 
repor os pactos em que assenta a nossa ideia de identidade (CORPO + NOME); os segundos querendo repor os pactos em que assenta a representação (COISAS / PALAVRAS). Não obstante, ambos acabam por alcançar apenas parcialmente o seu objectivo: aproximam-se das respostas acerca do que aconteceu, o que é fundamental em vários campos (o da justiça, o da verdade...), mas afastam-se das respostas ao que é uma catástrofe. O detido-desaparecido é-o; requer por isso um repensar de como fazer identidade e construir uma linguagem quando as acepções modernas de ambos os termos se vêem confrontadas com questões que as põem em cheque.

Tradução de Margarida Gomes

\section{Referências bibliográficas}

Agamben, Giorgio (1998), Homo sacer. El poder soberano y la nuda vida. Valencia: Pre-Textos.

Agamben, Giorgio (2002), El archivo y el testigo. Homo sacer III. Valencia: Pre-Textos. Amnistía Internacional (1983), Desapariciones. Barcelona: Fundamentos.

Ávila, Benjamín (2004), Nietos. Identidad y memoria (filme).

Bauman, Zygmunt (1997a), Legisladores e intérpretes. Sobre la modernidad, la posmodernidad y los intelectuales. Buenos Aires: Universidad Nacional de Quilmes.

Bauman, Zygmunt (1997b), Modernidad y holocausto. Toledo: Sequitur.

Béjar, Helena (1988), El ámbito intimo. Madrid: Alianza.

Blengino, Vanni (2005), La zanja de la Patagonia. Los nuevos conquistadores: militares, científicos, sacerdotes y escritores. Buenos Aires: FCE.

Calveiro, Pilar (2004), Poder y desaparición. Los campos de concentración en Argentina. Buenos Aires: Colihue.

CONADEP (1987), Nunca más. Buenos Aires: EUDEBA.

Donzelot, Jacques (1984), L'invention du social. Essai sur le déclin des passions politiques. Paris: Fayard.

Elias, Norbert, 1988, El proceso de la civilización: investigaciones sociogenéticas y psicogenéticas. México: FCE.

Elias, Norbert (1990), La sociedad de los individuos. Barcelona: Península.

Foucault, Michel (1990), Tecnologías del yo. Barcelona: Paidós.

Foucault, Michel (2006), Seguridad, territorio, población. Buenos Aires: FCE.

Gatti, Gabriel (2007), Identidades débiles. Una propuesta teórica aplicada al estudio de la identidad en el País Vasco. Madrid: CIS.

Gatti, Gabriel (2008), El detenido-desaparecido. Narrativas posibles para una catástrofe de la identidad. Montevideo: Trilce. 
Gómez Mango, Edmundo (2004), La desolación. De la barbarie en la sociedad contemporánea. Montevideo: Ediciones de la Banda Oriental.

González García, José Maria (2001), "Metáforas de la identidad. Nosce te ipsum”, in Juan Manuel Iranzo; Rubén Blanco (orgs.), Sobre las identidades. Lecciones Carlos Mendive (1998-1999). Pamplona: UPNA.

Grierson, Karl (1999), “Indicible et incompréhensible dans le récit de déportation”, La Licorne, 51.

Kaes, René (1991), "Rupturas catastróficas y trabajo de la memoria”, in Jeanine Puget; René Kaes (orgs.), Violencia de Estado y psicoanálisis. Buenos Aires: Centro Editor de América Latina.

Kaufmann, Laurent; Guilhaumou, Jean (2003), "Présentation”, Raisons Pratiques, 14.

Kordon, Diana; Edelman, Lucía (2005), “Efectos multilaterales de la represión”, Brecha, 1010 .

Levi, Primo (1989), Los hundidos y los salvados. Madrid: Muchnik.

Lewkowicz, Ignacio et al. (2003), Del fragmento a la situación. Notas sobre la subjetividad contemporánea. Buenos Aires: Altamira.

Lewkowicz, Ignacio (2004), Pensar sin Estado. La subjetividad en la era de la fluidez. Buenos Aires: Paidós.

Lo Giudice, Alicia (s/d), "Derecho a la identidad” (http://www.abuelas.org.ar, acedido em Novembro de 2007).

Moya, Carlos (1984), Señas de Leviatán. Madrid: Alianza.

Rama, Ángel (1998), La ciudad letrada. Montevideo: Arca.

Steiner, George (1982), Lenguaje y silencio. Barcelona: Gedisa.

Sucasas, Alejandro (2002), "Primo Levi: el nacimiento del testigo", in Reyes Mate (org.), La filosofía después del Holocausto. Barcelona: Riopiedras.

Vezzetti, Hugo (2000), "Representaciones de los campos de concentración en Argentina", Punto de Vista, 68.

Vezzetti, Hugo (2002), Pasado y presente. Guerra, dictadura y sociedad en la Argentina. Buenos Aires: Siglo XXI. 